DOI https://doi.org/10.18551/rjoas.2018-09.39

\title{
INFLUENCE OF TAX SOCIALIZATION AND LEVEL OF TRUST ON TAXPAYER COMPLIANCE AS A MICRO, SMALL AND MEDIUM BUSINESS ACTOR
}

\author{
Kharisma Ade Noorlita \\ Department of Accounting, Faculty of Economics and Business, \\ University of Airlangga, Indonesia \\ E-mail: enoorlitak@gmail.com
}

\begin{abstract}
This research aims to analyze the effect of the socialization of taxation and taxpayer trust level to personal tax compliance. The population used in this research is a micro, small \& medium business actor. The type of data used in this research is the primary data, the data obtained by questionnaires. There are 34 research samples to be tested. Data were analyzed using an analysis tool that consists of testing the quality of the data, descriptive statistics, test classic assumptions and hypothesis testing with SPSS. The results show that socialization taxation and taxpayer trust level effect on tax compliance.
\end{abstract}

\section{KEY WORDS}

Taxpayer, compliance, taxpayer, trust level, socialization, taxation.

Micro, Small and Medium Enterprises (MSMEs) are likened to a pioneer of a capable nation transformed as a savior god when the nation experienced a downturn. Economy in Indonesia is actually actually driven by MSME actors. Based on data from Ministry of Cooperatives and Small and Medium Enterprises as of June 2013, currently there are 55.2 million MSMEs or 99.98 percent of the total business units in Indonesia. In addition, this MSMEs absorbs 101.72 million people employment or 97.3 percent of the total Indonesian workforce. MSMEs also contributed 57.12 percent of gross domestic product (GDP) or Rp. 8,200 trillion. (Kompas, 28 June 2013). From the amount of state revenue coming from the MSME sector, it will have a large potential also the amount of tax revenue from the sector. The number of MSMEs that are increasing year by year increasing, providing opportunities for the government to target this sector in an effort tax extensification. However, this is not easy because there are various possibilities interpretation based on perceptions of MSMEs taxpayers.

Kurniawan, Kumadji and Yaningwati (2014) argue that taxation socialization is one program / activities implemented by the Directorate General of Taxes to improve understanding and knowledge of the community regarding taxes and to support implementation taxation services. Taxation socialization helps improve the perceptions of the perpetrators business about the importance of paying taxes. Lack of socialization may have an impact on low public knowledge about taxes that causes low awareness the community to report and pay taxes which might ultimately cause low level of taxpayer compliance (Winerungan, 2013). By giving understanding to Taxpayers regarding the tax function, indirectly giving awareness to Taxpayers on tax compliance. In addition to improving tax compliance, Tax socialization also affects taxation knowledge for taxpayers. Taxation knowledge is an impact caused by tax socialization and also potentially increases tax compliance

In some developed countries that impose taxpayers, citizens get benefits from the State, such as benefits for the unemployed, free health benefits, free basic education, convenient transportation, etc. (Handayani et al, 2012). If Taxpayers perceive that the state can be trusted in managing finances and can utilizing a budget that comes from taxes well, then the level of trust is mandatory tax will increase, as well as the level of taxpayer compliance. This is in line with Handayani et al (2012) which state that the level of taxpayer trust affect taxpayer compliance and contrary to research Cahyonowati (2011) who stated that taxpayer trust had no effect on Taxpayer compliance. 
Tax compliance is the willingness of individuals and other taxable entities to act in accordance with the spirit and tax law and administration letters without application of enforcement activities (James, 2010). Tax compliance leads more to individual awareness in doing tax obligations which with tax will be able to develop the country well, while the Taxpayer is a subject who has the responsibility to fulfill tax obligations through its contribution to paying taxes (Widodo, 2010 in Nashrudin, Bashori and Mustikasari, 2014).

Theory and Development of Hypotheses. Slippery Slope proposed by Kirchler et al (2008) is a concept integrating economic and psychological determinants of tax compliance. This framework shows that the effectiveness of economic and non-economic factors depends on the relationship between payers' tax and tax authority. In a climate of trust, action builds confidence may be more important than in relationships based primarily on the power of authority, where prevention may be the right policy (Muehlbacher et al., 2011).

Taxation socialization according to Ananda et al (2015) is an DGT effort (Directorate General of Taxes) provides information and guidance to Taxpayers regarding everything something that is correlated with the taxation field. Or it could be said socialization taxation is an effort to improve public understanding and awareness about tax rights and obligations.

Taxpayers' level of trust is a measure of how much trust they have Taxpayers' ownership of the legal system and government in Indonesia has been carried out with fair and right. The main focus of the taxpayer's level of trust is how that relationship is there is currently between the state and its citizens. Trust is something that is expected from honesty and cooperative behavior based on sharing norms and values the same (Doney et al., 1998 in Handayani et al., 2012).

Taxpayer compliance according to Prihartanto and Pusposari (2014) is a mandatory condition Taxes carry out their obligations, in discipline, in accordance with the laws and regulations and the prevailing tax method. Whereas Rantung and Adi (2009) define it as a value someone is willing to contribute (which is determined by regulation) used to finance public expenditure by not receiving lead services (counterpart) directly. There are two kinds of compliance, namely (Rahayu and Lingga, 2009):

a. Formal Compliance is a condition in which a Taxpayer fulfills an obligation formal taxation in accordance with the provisions of the tax law.

b. Material Compliance is a condition in which substantive / substantive taxpayers fulfill all the provisions of the tax material, namely according to the contents and soul of the law taxation law.

Previous research. Kirchler et al. (2008) explain the use of frameworks that study factors coercive and voluntary tax compliance. The results of this study are the framework slippery slope promises a better understanding of taxpayer behavior and practices arrangements by highlighting the need to consider the power of authority, trust in their authority and dynamic interaction.

Primasari (2016) examines the factors that influence people's taxpayer compliance a person who does free work. The type of data used in this study is data primary, data obtained by distributing questionnaires. There are 74 research samples that can be obtained test. The results obtained that the understanding of taxpayers has an effect on taxpayer compliance, while tax policy, taxpayer awareness, taxpayer's level of trust, socialization Partial taxation does not affect taxpayer compliance.

Anwar and Syafiqurrahman (2016) analyze whether taxation knowledge mediates influence of taxation socialization on MSMEs Taxpayer compliance in Surakarta. Results this study proves that tax socialization has a significant positive effect on taxation knowledge and tax compliance. In addition, knowledge of taxation too significant positive influence on tax compliance while mediating influence tax socialization of MSMEs taxpayer tax compliance in Surakarta.

Effect of Tax Socialization on Taxpayer Compliance. Socialization is done by educating individuals about the culture that must be owned and he followed, so he became a good member of the various groups and communities specifically, socialization can be considered the same as education (Sudrajat and Ompusunggu, 2015). With the good socialization and acceptable to the community, it is suspected that they are capable increase the motivation of 
taxpayers to comply with tax obligations. In line with the opinion of Sudrajat and Ompusunggu (2015) which states one factor that can emphasized by the authorities in improving tax compliance is by way of socializing tax regulations both through counseling, good moral calls with the media billboards, billboards, or opening tax regulation sites that can be accessed by Mandatory at any time Tax. So, the hypothesis in this study is:

$\mathrm{H} 1$ : tax socialization affects taxpayer compliance.

The Influence of Trust in Tax Authorities on Taxpayer Compliance. In many developed countries that impose tax obligations, every citizen get adequate support, such as education, health benefits, transportation and others. These direct and indirect benefits encourage taxpayers to fulfill their obligations to pay taxes with awareness full that they will get rewards through facilities that have been designed by government. Automatically the desire to deny the obligation to pay taxes will be eroded. Kirchler et al. (2008) explain in the slippery slope framework that the level of trust taxpayers to the tax authorities affect voluntary tax compliance.

H2: Taxpayer's level of trust affects taxpayer compliance.

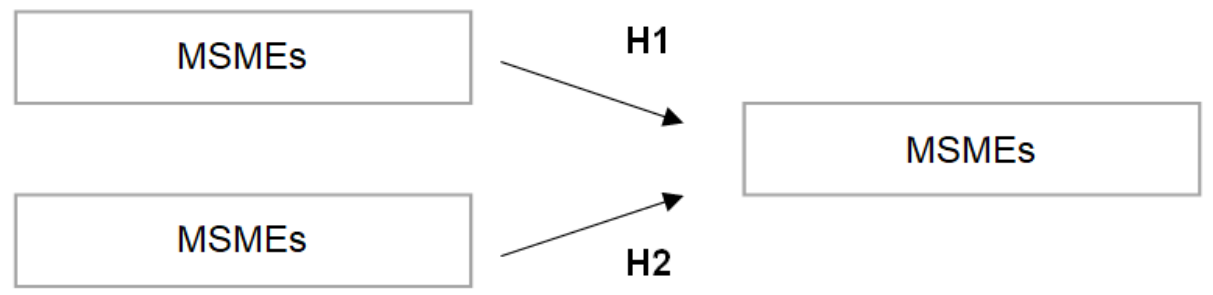

Figure 1 - Conceptual Framework

\section{METHODS OF RESEARCH}

This type of research is quantitative with an associative research approach. Associative research and correlational relationships and causal relationships between variables (Sulistyanto et al., 2006: 14). This research was conducted to the owners of SMEs in Surabaya.

Identify Variables:

- Dependent Variable in this research is tax compliance;

- Independent Variables used in this study are tax socialization and level of confidence. Operational Definition of Variables:

Tax Compliance. Taxpayer compliance is measured using 5 Likert scales. Likert scale 1 for Strongly Disagree up to 5 Likert scale for Strongly Agree. Indicator for compliance taxpayers are compliance to register, compliance to deposit back, compliance in calculating and paying tax payable, and compliance in payment tax arrears (Rahayu and Lingga, 2009).

Tax Socialization. Tax socialization is measured using 5 Likert scales. Likert scale 1 for Very Disagree with the Likert 5 scale for Strongly Agree. Indicator for tax socialization according to Winerungan (2013) is direct counseling, discussions with taxpayers and community leaders, Information directly from officers to taxpayers, Installation of billboards, Web sites DG Tax.

Level of Confidence. Trust Levels are measured using 5 Likert scales. Likert scale 1 for Very Disagree with the Likert 5 scale for Strongly Agree. Indicator for level of trust according to Handayani et al. (2012) Trust in the system of government, trust in legal system, trust in politics, and trust in tax collection re-allocated to the people.

\section{RESULTS AND DISCUSSION}

Analysis was carried out on 60 MSME players who had fulfilled the criteria for further. However, only 34 questionnaires can be received by researchers. The results of processing data regarding Descriptive statistics from respondents are presented in Table 1. 
Table 1 - General Description of Respondents

\begin{tabular}{|l|c|l|}
\hline Characteristics & Category & Amount \\
\hline Gender & $\bullet$ Men & 10 \\
& $\bullet \quad$ Women & 24 \\
\hline Turnover per Month & $\bullet \quad<$ Rp. 3.000 .000 & 20 \\
& $\bullet$ Rp. 3.000 .000 s/d Rp. 5.000 .000 & 5 \\
& $\bullet \quad>$ Rp. 5.000 .000 & 9 \\
\hline
\end{tabular}

Table 2 - One-Sample Kolmogorov-Smirnov Test

\begin{tabular}{|c|c|c|c|c|}
\hline & & TIS & T_TK & T_KP \\
\hline $\begin{array}{l}\text { N } \\
\text { Normal Parameters }{ }^{a, b} \\
\text { Most Extreme Differences } \\
\text { Kolmogorov-Smirnov Z } \\
\text { Asymp. Sig. (2-tailed) }\end{array}$ & $\begin{array}{l}\text { Mean } \\
\text { Std. Deviation } \\
\text { Absolute } \\
\text { Positive } \\
\text { Negative }\end{array}$ & $\begin{array}{l}34 \\
24,7059 \\
3,99643 \\
165 \\
, 108 \\
-165 \\
, 963 \\
, 312\end{array}$ & $\begin{array}{l}34 \\
34,5882 \\
3,76682 \\
132 \\
075 \\
-132 \\
768 \\
597\end{array}$ & $\begin{array}{l}34 \\
37,1176 \\
5,52002 \\
198 \\
198 \\
-155 \\
1,154 \\
140\end{array}$ \\
\hline
\end{tabular}

Normality Test Analysis is done by using one sample Kolmogorov Smirnov Test. In Table 2 it can be seen that the data in each variable is distributed normal. In table 2 it can be seen that the significance value for the tax socialization variable is 0.312 ; variable confidence level 0.597; and for the tax compliance variable 0.140. the data is said to be normally distributed if the significance value is greater than 0.05 .

Table 3 - Validity and Reability of Tax Socialization

\begin{tabular}{|c|c|c|}
\hline $\mathrm{n} / \mathrm{n}$ & Pearson Correlation & Cronbach's Alpha \\
\hline $\mathrm{S} 1$ &, 774 & \\
\hline S2 &, 908 & \multirow{2}{*}{, 895} \\
\hline S3 &, 811 & \\
\hline S4 &, 787 & \\
\hline S5 &, 811 & \\
\hline S6 &, 906 & \\
\hline
\end{tabular}

In table 3 above, the validity and reliability tests on the tax socialization variable are carried out. Test the validity states that the question item on tax socialization can be said to be valid because the Pearson correlation value $>0.3$. Reliability test states question items on variables this can be said to be reliable.

Table 4 - Trust Level Validity and Reliability

\begin{tabular}{|c|c|c|}
\hline & Pearson Correlation & Cronbach's Alpha \\
\hline TK1 & 817 & \\
\hline TK2 &, 824 & \\
\hline TK3 &, 782 \\
\hline TK4 &, 618 & \multirow{2}{*}{, 828} \\
\hline TK5 &, 705 & \\
\hline TK6 &, 568 & \\
\hline TK7 &, 549 & \\
\hline TK8 &, 595 & \\
\hline
\end{tabular}

In table 4 above, the validity and reliability tests are performed on the Level of Trust variable The validity test states that the item question on tax socialization can be said valid because the Pearson correlation value $>0.3$. Reliability test states question items on variables this can be said to be reliable.

In Table 5 above, the validity and reliability tests on the Tax Compliance variable are carried out. Test the validity states that the question item on tax socialization can be said to 
be valid because the Pearson correlation value $>0.3$. Reliability test states question items on variables this can be said to be reliable.

Table 5 - Tax Compliance Validity and Reability

\begin{tabular}{|c|c|c|}
\hline & Pearson Correlation & Cronbach's Alpha \\
\hline KP1 &, 901 & \\
\hline KP2 &, 781 & \\
\hline KP3 &, 917 & \multirow{2}{*}{, 969} \\
\hline KP4 &, 898 & \\
\hline KP5 &, 922 & \\
\hline KP6 &, 857 & \\
\hline KP8 &, 920 & \\
\hline KP9 &, 945 & \\
\hline
\end{tabular}

Table $6-T$ test

\begin{tabular}{|l|l|l|l|l|l|}
\hline \multirow{2}{*}{ Model } & Unstandardized Coefficients & Standardized Coefficients & & Sig. \\
\cline { 2 - 4 } & B & Std. Error & Beta & & \\
\hline (Constant) & 2,456 & 5,695 & &, 431 &, 669 \\
1 T_S &, 649 &, 239 &, 470 & 2,709 &, 011 \\
T_TK &, 539 &, 254 &, 368 & 2,121 &, 042 \\
\hline
\end{tabular}

Based on the partial test results the causality relationship between the dependent variable and Independent variables are indicated by the significance value of the regression coefficients of each variable independent compared to the value of $\alpha=0.05$. If the significance value <from $\alpha=0.05$, then the research hypothesis will be accepted, on the contrary if the significance value $>\alpha=0.05$, then the hypothesis research will be rejected. From table 6 shows that the significance value of the tax socialization variable and the confidence level is smaller than 0.05 , meaning that for the two variables affect taxpayer compliance.

Table 7 - Test $\mathrm{F}$

\begin{tabular}{|l|l|l|l|l|l|}
\hline Model & Sum of Squares & df & Mean Square & F & Sig. \\
\hline Regression & 625,328 & 2 & 312,664 & 25,493 &, $000^{\mathrm{D}}$ \\
1 Residual & 380,201 & 31 & 12,265 & & \\
Total & 1005,529 & 33 & & & \\
\hline
\end{tabular}

The F statistic test is used to indicate whether all independent variables are entered in this study, it is quite fit as a predictor of the dependent variable Taxpayer compliance. Results $\mathrm{F}$ test in table 7 is sufficiently independent variable as a predictor of the dependent variable. This can be seen from the calculated $F$ value of 25,493 with a smaller probability of 0,010 from 0.05 .

\section{CONCLUSION}

Based on the results of the regression equation test model can be seen that socialization taxation has a significant effect on MSME taxpayer tax compliance. Getting more positive taxation dissemination of tax compliance, the higher the level tax compliance. On the contrary, the tax socialization of compliance is increasingly negative taxation, the lower the level of tax compliance. This result rejects the findings Winerungan (2013) who said Taxation socialization had no effect on Personal Taxpayer Compliance and supports the findings of Kurniawan, Kumadji and Yaningwati (2014) which concluded taxation socialization partially had a significant effect on awareness of taxpayers in paying taxes. The results also state that level trust has a positive effect on taxpayer compliance with trust in the system law and taxation have an effect on personal taxpayer compliance. Results research is in line with 
Handayani et al. (2012), but is not consistent with research Cahyonowati (2011), which states that trust in tax laws and regulations does not affect taxpayer compliance, it is due to external factors like fines are more dominant influential.

For further research, it is expected to be able to test factors outside the variable independent researches such as education level, tax sanction, tax audit, e-system and others. Expanding the research population, maybe it can be up to one island of Java or Indonesia as a whole, it is expected that the conclusions of this study can be generalized to Taxpayer population in Indonesia.

\section{REFERENCES}

1. Ananda, P. R. D. Kumadji, S. Husaini, A. (2015). Pengaruh Sosialisasi Perpajakan, Tarif Pajak, Dan Pemahaman Perpajakan Terhadap Kepatuhan Wajib Pajak (Studi pada UMKM yang Terdaftar sebagai Wajib Pajak di Kantor Pelayanan Pajak Pratama Batu). Jurnal Perpajakan (JEJAK). Vol. 6 No. 2.

2. Anwar, R. A. (2016). Pengaruh Sosialisasi Perpajakan terhadap Kepatuhan Perpajakan Wajib Pajak Usaha Mikro Kecil Dan Menengah (UMKM) di Surakarta dengan Pengetahuan Perpajakan sebagai Variabel Pemediasi. InFestasi, 12(1), 66-74.

3. Cahyonowati, N. (2011). Model Moral dan Kepatuhan Perpajakan: Wajib Pajak Orang Pribadi. Jurnal Akuntansi dan Auditing Indonesia (JAAI). Vol. 15 No. 2, 2011: 161-177.

4. Handayani, Sapti Wuri. Faturokhman, Agus. Dan Pratiwi, Umi. (2012). Faktor-Faktor Yang Mempengaruhi Kemauan Membayar Pajak Wajib Pajak Orang Pribadi Yang Melakukan Pekerjaan Bebas. Simposium Nasional Akuntansi 15. Banjarmasin.

5. James, S., 2004. Tax Compliance, Self-Assessment and Tax Administration.Journal of Finance and Management, Vol. 1, No. 2, September, pp. 27-42.

6. Kamleitner, B. (2012). Tax compliance of small business owners: A review. International Journal of Entrepreneurial Behavior \& Research, 18(3), 330-351.

7. Kirchler, E., Hoelzl, E., \& Wahl, I. (2008). Enforced versus voluntary tax compliance: The "slippery slope" framework. Journal of Economic Psychology, 29(2), 210-225.

8. Kogler, C., Muehlbacher, S., \& Kirchler, E. (2015). Testing the "slippery slope framework" among self-employed taxpayers. Economics of Governance, 16(2), 125-142.

9. Muehlbacher S, Kirchler E, Scharzenberger H (2011). Empirical evidence for the "slippery slope" framework. Eur. J. Law Econ., 32(1): 89-97.

10. Nashrudin, A., 2014. Pengaruh Persepsi atas PP No 46 Tahun 2013 terhadap Kepatuhan Sukarela Wajib Pajak yang Memiliki Peredaran Bruto Tertentu pada Kantor Pelayanan Pajak Pratama Surabaya Rungkut. Working Paper, Universitas Airlangga.

11. Prihartanto, C. D. (2014). Analisis Faktor-Faktor Yang Mempengaruhi Kepatuhan Wajib Pajak Dalam Melakukan Pembayaran Pajak Bumi Dan Bangunan Perdesaan Dan Perkotaan (Studi kasus pada wajib pajak PBB P2 Kecamatan Pesantren Kota Kediri). Jurnal IImiah Mahasiswa FEB Universitas Brawijaya.Vol 2, No 1.

12. Primasari, N. H. (2016). Faktor-faktor yang mempengaruhi kepatuhan wajib pajak orang pribadi yang melakukan pekerjaan bebas. Jurnal Akuntansi dan Keuangan, 5(2).

13. Rahayu, S., Lingga, I. S. (2009). Pengaruh Modernisasi Sistem Administrasi Perpajakan terhadap Kepatuhan Wajib Pajak (Survei atas Wajib Pajak Badan pada KPP Pratama Bandung "X"). Jurnal Akuntansi. Vol.1 No.2 November 2009:119-138.

14. Rantung, T. V. (2009). Dampak Program Sunset Policy Terhadap Faktor-Faktor yang Mempengaruhi Kemauan Membayar Pajak (Studi pada Wajib Pajak Orang Pribadi Pelaku Usaha di Wilayah KPP Pratama Salatiga). Simposium Nasional Perpajakan II.

15. Sudrajat, Ajat dan Ompusunggu, A. P. (2015). Pemanfaatan teknologi Informasi, Sosialisasi Pajak, Pengetahuan Perpajakan, dan Kepatuhan Pajak. Jurnal Riset Akuntansi dan Perpajakan JRAP. Vol. 2, No. 2, Desember 2015, hal 193 - 202.

16. Winerungan, Oktaviane Lidya. 2013. Sosialisasi Perpajakan, Pelayanan Fiskus Dan Sanksi Perpajakan Terhadap Kepatuhan WPOP Di KPP Manado Dan KPP Bitung. Jurnal Riset Ekonomi, Manajemen, Bisnis dan Akuntansi (EMBA). Vol.1 No.3. Hal. 960-970. 